\title{
The Civic Education Crusade: A Heretic's Analysis
}

\author{
Carl L. Bankston III
}

Published online: 8 October 2013

(C) Springer Science+Business Media New York 2013

In January 2012, the National Task Force on Civic Learning and National Engagement of the Association of American Universities and Colleges released its report, A Crucible Moment: College Learning and Democracy's Future. The report called for a program of civic learning and of training in civic engagement that would pervade every aspect of higher education. This program would be linked to similar efforts at all other levels of schooling. In the words of the report, "[t]he central work of advancing civic learning and democratic engagement in higher education must, of course, be done by faculty members across disciplines, by student affairs professionals across divisions, and by administrators in every school and at every level. The fourth prominent group of actors are the students themselves [bold in the original]. The collective work of these groups should be guided by a shared sense that civic knowledge and democratic engagement, in concert with others and in the face of contestation, are absolutely vital to the quality of intellectual inquiry itself, to this nation's future, and to preparation for life in a diverse world" (p. 2). It called for fostering "a civic ethos across all parts of campus and educational culture" (p. 31) (See: http://www.aacu.org/civic_learning/ crucible/documents/crucible_508F.pdf).

Although the report was not particularly original or wellwritten, I read it with interest for several reasons. First, I am one of those "faculty members" mentioned in the report, and I always pay attention when people want to re-write my job description. Second, I work in a university in which "civic engagement" became the official dogma a half-decade ago . Third, I recently published a book on education as American civil religion and I see the contemporary civic engagement movement as an extension of our national educational faith. In

C. L. Bankston III ( $₫)$

Department of Sociology, Tulane University, 220 Newcomb Hall, New Orleans, LA 70118, USA

e-mail: cbankst@tulane.edu the present essay, I want to pass over the personal sources of interest and focus on the third. Looking at the effort to use instruction for citizenship training as a development of civil religion can help us understand the reasoning and motivations behind this effort and some of the problems with this type of campaign, particularly in higher education.

\section{Background: The History of American Education as Civil Religion}

In Public Education-America's Civil Religion: A Social History (2009), Stephen J. Caldas and I drew on sociologist Robert N. Bellah's concept of American civil religion to look at the development of American schooling. We argued that Bellah's controversial idea was not only useful for understanding the history of education in this country, but that his three major periods in the national faith (from the founding to the Civil War, from the Civil War to the mid-twentieth century, and from the time of the civil rights movement onward) were closely linked to the development of ideas about schooling. We maintained that education was both a means of propagating the doctrines of civil religion and consistently a key tenet of those doctrines.

Looking at the period of the emerging common schools, during the first half of the nineteenth century, we found that influential Americans of the time already saw schooling as a way to remake the nation and to remake their fellow citizens according to an ideal national image. As early as 1800, Noah Webster's Blue Backed Speller presented a "Federal Catechism," aimed at inculcated a Constitutional and Federalist set of beliefs, as well as a social morality. By the second third of the century, educators such as Horace Mann were describing the commons schools as the machinery that could produce the right types of citizens for American democracy. These educators often sounded utopian in their faith in 
the power of universal schooling to create a new order of the ages. Based mainly in the northeast, the apostles of education often pointed to the widespread availability of schooling in their region as one of the keys to their superiority over the slave states. When the Civil War ended, missionary efforts at spreading schooling among freedmen and others played a large part in Reconstruction.

American educational ideology as we know it today derives some its character from the era of the common schools. But our modern institution of education is really a post-Civil War phenomenon. Schools and especially the system of public schooling spread throughout the U.S. as it entered a period of unification in the late nineteenth and early twentieth century. Nationalism was one of the great themes of the Progressive Era, the time that shaped schooling as an institution in this country. During the heyday of Progressivism, schools became central to the American civil religion in two respects. First, they were means of conveying beliefs about the nation. Flag ceremonies, the pledge of allegiance, national celebrations, and reverential narratives of the founders became standard events in American public schools, which served as churches of the American civil religion. Second, public schooling itself took a key position in the American creed. Schools would create national unity; they would enable individuals to develop their talents according to their natures; they would train citizens for a democratic society; they would socialize an efficient workforce; they would create a new and more perfect society.

One effect of the legacy of Progressive education was to firmly establish the idea that schooling was the way in which American society could reach the fullness of its ideals. The period between the two World Wars saw a continuation and extension of Progressive education. On the one hand, the idea of education as a means of cultivating nationalism and shaping the future citizenry for economic and civic participation became deeply entrenched. On the other, Progressive educators throughout the twentieth century saw schools as tools for engineering a better society. For example, the influential "social reconstructionist" George S. Counts believed that the American people needed to be transformed in order to be suited to his vision of the American future, and that schools were the places to achieve the transformation. In his pamphlet, The Schools Can Teach Democracy, initially delivered as an address before the Progressive Education Association on Washington's Birthday in 1939, Counts argued that the proper business of schools was to create a democratic society through cultivating "democratic habits, dispositions, and loyalties," as well as relevant political knowledge in students (p. 22). Through schooling, "the entire nation would be subjected to the most critical examination for the purpose of revealing submerged and exploited regions, occupational groups, and racial, national, and religious minorities" (p. 26).
World War II and the Cold War intensified the emphasis on the nationalistic side of the American creed in schools. In addition, the postwar period saw the beginning of greater federal involvement in schooling. Although nationalism had long been at the heart of the civic faith taught by the schools, education had always been highly local in its support and control. As federal participation increased, Americans also spent much greater portions of their lives in educational institutions. By the 1950s, the overwhelming majority of Americans were finishing high school and growing numbers were going on to college. Expanding economic opportunities, often linked to rising levels of formal education, fostered the belief that upward mobility should be available to all and gave a new twist to the doctrine of social reconstructionism in American education. Americans believed both that everyone should be better off in the surrounding abundance and that each individual should get ahead through free competition. With their history of national faith in education, Americans often portrayed schools simultaneously as fields of meritocratic competition and as arenas of equalization. With ever greater proportions of the student population going on to college, belief in schooling as the means to create a more prosperous, just, and egalitarian future began to include higher education, as well as the primary and secondary levels.

The most recent great crisis in American civil religion came in the 1960s and 1970s, with the civil rights movement and its immediate aftermath. Schooling continued to be both a vehicle of faith and an article of faith, but the moral drama of the movement reshaped the tenets of national beliefs. The defining characteristic of this reshaping was a heightening of the emphasis on egalitarian goals, especially through the inclusion of disadvantaged categories of people. Following the turning point of this era, a new and intensified social reconstructionism came to dominate the thinking of many educational theorists. In schools Americans would be taught the values of diversity, inclusion, and tolerance. Schools themselves could be re-structured in order to remake American society. "If we want a segregated society," remarked the eminent social scientist Christopher Jencks in his 1972 book Inequality, "we should have segregated schools. If we want a desegregated society, we should have desegregated schools" (p. 106). The comment sounds incontrovertible: what reasonable person, especially in the post-civil rights movement era, wants a racially segregated society? But it betrays the belief that it is possible to change an entire society by changing its schools. Educational institutions would be the means of creating an egalitarian and inclusive future and the means of propagating commitment to an ideology of egalitarianism and inclusiveness.

The federal government became even more active in education from the time of the civil rights movement onward and improving American society through the schools became 
central to federal education policy. In 1965, urged by President Lyndon Johnson, Congress passed the Elementary and Secondary Education Act (ESEA), which made large sums of money available to school districts. However, this money could be withheld from districts that failed to comply with the provisions of the Civil Rights Act, passed the previous year. As part of the War on Poverty, moreover, Title I of the ESEA directed funds to schools and school districts that held high percentages of low-income students.

Federal support for higher education grew at the same time, promoted by similar social reconstructionist aims. In November 1965, President Johnson proudly signed the Higher Education Act (HEA). The HEA provided needbased scholarships, part-time jobs, and interest-free loans for low-income students, with the idea that all high school graduates should be able to go on to higher education. The HEA was conceived of as a partner to the ESEA, bringing higher education into closer coordination with elementary and secondary schooling.

In 1972, Congress made new provisions for subsidizing the college educations of low-income students in postsecondary schooling when it introduced Basic Educational Opportunity Grants, which became known as Pell Grants after Rhode Island Senator Claiborne Pell, who was the bill's primary sponsor. For those judged to have exceptional financial need, Pell Grants were later supplemented with Federal Supplementary Educational Opportunity Grants. By the 1970s, then, the national faith in education had taken a definite turn toward social reconstructionism, federal involvement in education had increased greatly, and all levels of schooling were becoming more tightly coordinated. The social reconstructionist ideology and the close integration of educational institutions and government became the foundations of the contemporary civic engagement movement.

\section{The Rise of the Civic Engagement Movement}

The belief in education as a vehicle for teaching a doctrine of social reform and a means of bringing about social reform took firm hold in the years around the civil rights movement. The National Service-Learning Clearinghouse begins its history of service learning, a central facet of the civic engagement movement, by recounting that " $[t]$ he civil rights movement of the 1960s, and the formation of the Peace Corps in 1961, and Volunteers in Service to America (VISTA) in 1965 brought a new passionate energy to activist education by engaging young people and giving them real opportunities to make a difference in the world. It was during this time period that the early pioneers of the service-learning movement began to emerge and attempted to combine 'service' to 'learning' in a direct and powerful way" (See: http://www.servicelearning. org/history-service-learning-higher-education).
The Clearinghouse website tells us that this sixties-era passion to put learning in the service of social causes led to conference on college service learning in Atlanta in 1969, sponsored by the Southern Regional Education Board, the City of Atlanta, the Atlanta Urban Corps, Peace Corps, Vista, and the U.S. Department of Health, Education, and Welfare. The conference ultimately recommended that all colleges and universities should encourage community service, integrate it into academic activities, and give academic credit for community service. Institutions of higher education, the conference suggested, should make opportunities and funds available for service learning. Finally, community service and service learning should be planned and run by students, faculty, and public and private agencies.

Barbara Jacoby and Associates, authors of the manual Civic Engagement in Higher Education: Concepts and Practices (2009) agree that the push for service learning that came out of 1960s activism gave rise to the modern civic engagement movement. While the movement started with the activist commitments of individuals, though, from this very beginning the movement clearly entailed efforts to institutionalize these commitments and to make them into totalizing government-college programs, in which all students, faculty, and officials would work together to affirm officially approved beliefs about citizenship and social and to put these beliefs into practice.

Jacoby and Associates trace the rise of a new wave of civic engagement advocates to the 1980s and 1990s, when many in academic and policy making circles became concerned that Americans were excessively individualistic and that this was undermining the nation's cooperative foundations. My coauthor and I have argued the 1980s and 1990s were a time of anxiety about the nation's economic competitiveness and that a new emphasis on standardized testing and on nationwide educational goals grew out of the historically shaped civic faith that all public problems are rooted in education and can be solved through education. This faith combined with the heightened federal involvement and tightened coordination of levels of schooling to produce the first nation-wide goals for American education in George H.W. Bush's utopian "Goals 2000," created between the Charlottesville Education Summit and the Goals 2000 Act of 1994. This anxiety over the country's future and the faith in education as the answer to all problems also produced the National and Community Service Act, which the same President Bush signed into law in 1990 to support service learning and service programs for students at all levels, including college students. Under the guidance of the federal government, every level of education would be standardized and coordinated to serve national goals and to consolidate Americans into a committed and cooperative national community.

Calls for service and engagement drew heavily on popular versions of social capital theory. This theoretical perspective 
most often argues that social ties are investments that people make in each other that help them achieve individual and collective goals. The most influential social capital argument during the 1990s shared the general anxiety over the state of American civic health. This was the "bowling alone" argument of political scientist Robert Putnam, who maintained that the participation of Americans in communal activities, such as bowling leagues, parent-teacher organizations, and clubs had declined and that this decline was indicative of a loss of national social capital. Readers of Alexis de Tocqueville may recognize this as an updated version of Tocqueville's identification of voluntary associations as the foundation of American democracy. Rebuilding America's supposedly diminishing stock of social capital through promoting the civic involvement of citizens became one of the main goals of the educational social reconstructionists by the beginning of the twenty-first century.

The new wave of federally supported and encouraged community service in schools accompanied federally promoted standardized educational assessments throughout the administrations of the three presidents who followed the first President Bush. The Clinton Administration, for example, presided over the passage of the National and Community Service Trust Act of 1993, which created the Corporation for National and Community Service.

The American Association of Colleges and Universities (AAC\&U) has been an outspoken advocate for servicelearning and civic engagement education. It should be noted that the AAC\&U is a highly politicized organization with its own distinctive view of how American society should be reconstructed and a fondness for expressing this view in the millenarian rhetoric of "struggles" and "calls to action." Immediately after the election of President Barack Obama in 2008 , the AAC\&U issued a statement applauding the president's election as a "...historic moment made possible by many years of struggle" (See: https://www.aacu.org/about/ statements/2008electionstatement.cfm). Not surprisingly, the AAC\&U has had close ties to the Obama administration and its task forces operate as federal policy planning committees.

The AAC\&U's most recent task force on Civic Learning and Democratic Engagement released its "call to national action" at an official White House event with the melodramatic title, "For Democracy's Future: Education Reclaims Our Civic Mission," sponsored by the White House Office of Public Engagement and the U.S. Department of Education. A Crucible Moment builds on the belief that education offers the means of meeting the individual needs of all Americans and reconstructing American society. It cites a breathtaking array of "pressing issues," including "growing global economic inequalities, climate change and environmental degradation, lack of access to quality health care, economic volatility, and more." The answer to all of these problems lies in "expanding students' capacities to be civic problemsolvers." The report does not go into detail about how the professors and teachers, who do not necessarily possess such great social problem solving skills, will produce this generation of superbeings, but it does recommend that institutions foster what is variously called a "democratic ethos" and a "civic ethos" on every campus through "service learning" and "community engagement." Whatever its limitations, this federally sponsored report certainly does not fall short in its belief that through education all things are possible.

\section{The Civic Education Doctrine and Higher Education: Problems and Contradictions}

In pointing out that education has historically been a central element in the evolving American national faith, I am not suggesting that commitment to the American nation per se is a bad thing, nor am I suggesting that schooling has no part to play in socializing young Americans, producing a thoughtful and knowledgeable citizenry, or preparing us to meet the demands of our economy. The danger of faith, though, is that it tends to lead us to assume rather than to examine. In this case, we tend to take education as a panacea. We do not consider carefully what it can do and what it should do. We often take it as simply given that problems such as national competitiveness and unequal opportunities for social mobility can be solved by coming up with the right plan for the schools. In seeing education as the answer to everything, we are tempted to extend the bureaucratic reach of formal schooling to every area of life. Instead of "de-schooling" society as Ivan Illich advocated, we try to move toward a total schooling of society and everyone in it. This is precisely where I find the civic engagement trend in our belief in education goes beyond what schooling should do in a liberal democracy.

By the second decade of the 2000s, in many circles of academia and government the question was not whether everyone in primary and secondary schools, higher education, and government should collaborate in training students for social and political involvement but how they should do so. This unthinking commitment is disturbing because it overlooks the paradoxical nature of faith in education as a means of building a democratic nation.

When Alexis de Tocqueville described voluntary associations as a basis for American democracy, he was referring to associations that the people themselves had formed of their own will, not public commitments decided upon and directed by the collaboration of governmental and educational bureaucracies. While different people and different political philosophies use the word "democracy" in a variety of ways, the 
term most commonly refers to a system of government in which people either make political decisions for themselves (direct democracy) or elect representatives to make political decisions (representative democracy). In the former, there is no question of anyone "re-making" the people, since the people think for themselves and have the freedom to be what they are. In the latter, also, the goal of re-shaping a society along democratic lines is a contradiction because a representative government represents its public as it is; the government does not try to re-make its constituents.

Since a society is made up of people and of the total of formal and informal relations among people, changing a society means changing the people and their relations with each other. It is a profoundly authoritarian effort and even, as it approaches a goal of total reform, totalitarian at its extreme. Political reform is a matter of changing laws. Economic reform involves changing policies relating to matters such as taxation, public expenditures, or interest rates. Either of these may be consistent with democracy. But governmental reform of an ethos aims at changing people and their relations with each other. This is a reversal of the direction of action and control of a democratic society, since it involves the authorities attempting to constitute or re-constitute the public, rather than the public constituting the authorities. It is reminiscent of Bertolt Brecht's 1953 quip that the East German people had apparently lost the confidence of their government, so the government should "dissolve the people and elect another one." Creating a new society is precisely the attempt to dissolve the people as they are and to appoint the people as one would like them to be.

At the level of higher education, a crusade to build social capital poses special kinds of problems. Social capital refers to networks of social relations that promote efficacious action through the control and direction of network participants. I have found in my own work on ethnic networks as forms of social capital that the same tight community connections that promote the upward mobility and academic achievement of young people also penalize nonconformity. In other words, social capital is a mechanism for mobilization and social control. Communities that can mobilize and control their members can indeed engage in many constructive activities, but they also tend toward conformity in expression and behavior. We probably want high levels of social capital and high levels of conformity in some of our institutions, such as the military. Within families and many types of associations, limitations on individual freedom are often desirable. If a university is to be a forum for the open and free exchange of ideas, though, it must be a low social capital institution. Individuals in a university may be highly committed to their ideas and goals, but these must be their ideas and goals, not those approved and promoted by the institution. From the perspective of a traditional liberal education, colleges and universities are exactly where we should not be making blueprints for building social capital.

For a university or college to become a community of faith, as it must if it is to adopt promulgating civic engagement as its mission, it has to set up tenets of orthodoxy. Someone has to decide what constitutes appropriate "engagement." The institution may be relatively lenient in enforcement of doctrine and reluctantly tolerate heretics, but it cannot fulfill its mission without trying to get students and faculty to fall into line and march in the right direction. It is entirely appropriate for a religious organization to call its adherents to become soldiers of the faith. But few things are more inconsistent with the intellectual freedom essential to a university than the expectation that its students and faculty will become social missionaries. A regime of social commitment discourages intellectual diversity, even if it does not openly forbid it.

The word "heresy" comes from a Greek verb meaning "to choose." Heretics are those who do follow their own reason or inspiration instead of the correct teaching of the authorities. If we are to be intellectually free in higher education and not bound by orthodoxy, we must be free not simply to choose our own forms of public engagement but to choose disengagement. Take, for example, the American heretic Henry David Thoreau. Thoreau was decidedly disengaged. He wrote his most famous book while living alone in the woods. When he took his best-known stand on the public issues of his day, he did so by refusing to pay taxes and by denying the authority of the government. Whatever one thinks of Thoreau's heresy, taking disengagement of his sort or another has to be a legitimate option in a free forum of ideas.

The all-encompassing nature of the contemporary civic engagement movement makes the threat to intellectual diversity especially alarming. The report A Crucible Moment not only demands the participation of every person involved in education, but it insists that every course in every subject incorporate its message. Issued as "a call to national action," the social and political agenda it intends to implement in every classroom comes with the imprimatur of the U.S. Department of Education. As I read the report, I find its demands for inculcating a "democratic ethos" perplexing. Beyond the fact that in a liberal democracy neither the government nor committees sponsored and subsidized by the government decide what type of ethos the people should have, the ideal of integrating all levels of schooling into a unified social program, and inserting this program into every subject appears to be promoting a kind of new bureaucratic corporatism, aimed at absorbing everything into the state and leaving nothing outside the state. 
The proper response to dramatic calls to national action might be to temper our faith in the education with reflection, examination, and careful criticism. Universities and colleges can make available to students advanced intellectual skills, in abstract reasoning and analysis. They can provide access to practical skills and to the cultural heritage of humanity. They can furnish forums for sharing ideas from all perspectives. But we put the things these institutions can do at risk if we make education a vehicle for a committee's vision of social reconstruction. The incorporation of a mandated social creed into the "mission statements" of institutions limits the operation of reason. Directing all courses of study along lines that an administration or a task force have decided serve the mission of social reconstruction subordinate the teaching of practical skills and the humanities to ideological direction. Most importantly, perhaps, civic action that derives from an institutional program, rather than from undirected individual decision, contradicts not only the principle of intellectual freedom, but the essential character of liberal democracy.

Carl L. Bankston III is professor of sociology at Tulane University. His research interests include sociology of education, international migration, historical sociology, and sociology of religion. He is author or editor of 18 books and over 100 journal articles. His most recent books have been Public Education - America's Civil Religion: A Social History (2009) and Forced to Fail: The Paradox of School Desegregation (2005). He is currently working on a book on social capital and social networks in immigration, to be published by Polity Press. 